\title{
Staff Assignment Rotation and Project Sustainability in South Sudan
}

\author{
Abraham Ansu Kanneh ${ }^{1} \&$ Olawumi Dele Awolusi ${ }^{2}$ \\ ${ }^{1}$ Department of Business Administration, the Business School, University of Roehampton, London, UK \\ 2Department of Accounting and Finance, College of Economics and Management, Kampala International \\ University, Kampala, Uganda \\ abraham.kanneh@roehampton-online.ac.uk, awolusi.olawumi@kiu.ac.ug
}

\begin{abstract}
The primary objective of this study was to determine the existence of a causal relationship between Staff Assignment Rotation vis-à-vis Project Sustainability in South Sudan. The research followed the qualitative methodology predicated on the "philosophical dimensions" of constructivism and interpretivism. The participants for the research consisted of 50 individuals drawn from four population groups: Refugees as the primary beneficiaries, humanitarian workers and project staff. Qualitative data collection was chosen as the research methodology and in-depth interview and focus group discussion as the research techniques in the data collection. Narrative analysis was the method of data analysis. The study revealed that 81 percent of the respondents indicated security as the single most important factor that impacts project sustainability. Staff assignment rotation followed with 16 percent. Data analysis was compartmentalized and looked at the profile of the respondents to see any noticeable variance from the functional perspective. Contextualizing the data helped to balance any perceived unbiased in the responses based on their functional affinity. In addition to Security as the prominent factor that impacts project sustainability, staff rotation, government regulation, and funding could also impact significantly depending on the context. The study recommends a comprehensive review of the current mandatory policy to align the operation management cycle; encompassing the project initiation, planning, implementation, monitoring and closure to the standard assignment length of staff assigned to implement these projects.
\end{abstract}

\section{Keywords: Staff Assignment rotation; project sustainability; Constructivism; Interpretivist; South Sudan.}

\section{Introduction}

Staff Assignment Rotation is defined in the context of UNHCR, also known and shall be interchangeably referred, to as the UN Refugee Agency, as the mandatory transfer through an organized reassignment of international professional staff from one duty station to another upon completion of predetermined duration (UNHCR, 2017a). UNHCR applies the policy of staff assignment rotation, in particular to duty stations that have been classified as hardship, high-risk locations and non-family duty stations in consideration of the health and wellbeing of staff members who serve in these locations (Olayisade \& Awolusi, 2021; UNHCR, 2017b). Similarly, project sustainability is defined as satisfying our immediate and medium-term needs without disrupting the ability of future generations to meet their own needs (Awolusi, 2021). In this context, we will examine the impact directly or indirectly related to staff's temporary absence from the project site due to the application of the mandatory policy (UNHCR/AI/2017/7/Rev.1). The UN Refugee Agency was established through the UN General Assembly (UNGA) Resolution 428 (V) of 1950 where paragraph 1 of the Statute states that "The High Commissioner acting under the authority of the General.

Assembly shall assume the function of providing international protection, under the auspices of the United Nations, to refugees who fall within the scope of the present statute of seeking a permanent solution for the problem of refugees" (UNGA, 1950, P. 46-48). Over the past sixty years, the UN Refugee Agency has evolved into a global humanitarian organization with the 2017 final budget amounting to 7.963 billion in fulfilling the organizational mandate of international refugee protection including remote field locations. Ref: Figure 1 below for detailed budget information. UNHCR's growth has also been underpinned by its large representation globally. According to UNHCR Global Report 2017, the UN Refugee Agency is present in 130 countries with offices in 478 different locations. By December 2017, the workforce had reached 15,273; 11,423 Staff and 3,850 Affiliated Workforce. The report further indicates that $88 \%$ are field most in remote field locations which are designated D and E duty stations. According to UNHCR (2017a), D and E duty stations are mostly non-family locations with reduced Standard Assignment Length (SAL). 
Due to lack of basic facilities, insecurity and hazardous living and working conditions. Standard Assignment Length (SAL) is the length of time that a staff member serves on a position in a given duty station and the SAL of each staff member is predetermined based on hardship classification of the duty station (UNHCR, 2017a). Furthermore, according to section 4.3 .38 of UNHCR's Recruitment and Assignments Policy UNHCR/HCP/2017/2 (2017b) and revision one of the Recruitment and Assignments Administrative Instructions UNHCR/AI/2017/7/Rev.1 (2017a), it is UNHCR's international professional staff members that are subject to mandatory rotation. "Rotation implies that each assignment is time-bound and its duration is normally determined by the hardship classification of the duty station (UNHCR, 2017b, p8)". Furthermore, section 4.3.41 of the same document provides further clarity on the duration by specifying that SALs normally end on either 30 June or 31 December. The SAL expiry will be 30 June for assignments starting between 1 April and 30 September, and 31 December for assignments starting between 1 October and 31 March (UNHCR, 2017a). The Republic of South Sudan, the subject of this impact analysis gained independence from Sudan on July 9, 2011. It (located in East-Central Africa) became the newest nation with a population of 12.23 million. In December 2013, it was engulfed in a brutal civil war which began as a political conflict between President, Salva Kiir and his then Vice President, Riek Machar. A power-sharing agreement, signed between the two parties in August 2015, did not end the fighting; following clashes in Juba in July 2016, Machar went into exile, where he remains (HRW, 2018).

According to the Human Rights Watch (HRW) World Report (2018) on South Sudan, following the start of the conflict in 2013, almost 2 million people were internally displaced, and another 2 million sought refuge in neighboring countries, with 1 million in Uganda alone. Of the internally displaced, more than 230,000 people were sheltering in six United Nations bases in towns across the country. The situation was further exacerbated by the declaration of famine, especially in conflict-affected areas in the former Unity State in the first half of 2017. According to news reports, more than 100,000 people in two counties of Unity state were found to be experiencing famine and there were fears it could spread as an additional one million South Sudanese were on the brink of starvation elsewhere in the country (Aljazeera.com, 2017). With these conditions, South Sudan presents a unique attribute that makes it an ideal setting to highlight the impact of Staff Rotation Assignment on project sustainability. Firstly, it was and remains one of the 17 most dangerous places in the world. (The Daily Telegraph, 2018). Secondly, during the period under review (2013-2016), it had one of the largest humanitarian interventions in the world, with more than 10,000 military and civilian personnel and the magnitude of human suffering was unprecedented, as 4 million were either internally displaced or sought refuge in neighboring counties. In the context of the UN Refugee Agency, (UNHCR), South Sudan was one of the largest operations in terms of Human and Financial Resources. It had more than 400 regular and affiliated workforce almost all of whom were subjected to the Mandatory Rotation Policy.

In terms of projects implemented either directly by UNHCR or by Implementing Partners (IPs) who were funded under the UNHCR budget to provide basic services, the total estimated amount from 2013-2016 was more than 500 million US dollars and specifically, from January to December 2016, the excerpts from UNHCR Global Report, 2017 indicates a total financial requirement of $\$ 701,606,726$ with 46 partners. As wars and other violence and persecution forced human displacement to more than 68 million in 2017, and as crises in the Democratic Republic of Congo, South Sudan continues unabated, and as the flight into Bangladesh from Myanmar of thousands of Rohingya refugees continue amid human tragedy, the humanitarian response requiring staff mobility to assist remains an absolute necessity. Furthermore, the resources required to address these challenges remain scarce (UNHCR, 2017b). Therefore, this study is carried out to determine the impact of Staff Assignment Rotation on the Sustainability of UNHCR supported projects in South Sudan in terms of social and economic components. To critically identify the extent to which staff mobility impacts project sustainability, this study put into perspective the Mandatory Staff Rotation Policy and independently evaluated Staff Rotation vis-à-vis Project Sustainability. According to the UN Refugee Agency revised policy on Recruitment and Assignments Administrative Instruction (2017a) and as detailed in figure 2 above, "UNHCR international Professional staff members are subject to mandatory rotation. Rotation implies that each assignment is time-bound and its duration is normally determined by the hardship classification of the duty station" UNHCR/AI/2017/7/Rev.1 (UNHCR, 2017a).

Operations Management Cycle: As stipulated in Chapter 4 of the UN Refugee Agency's Programme Manual, (Figure 3\&4) (UNHCR, year of manual), the program cycle is designed to cover three years period 
encompassing the previous year, the current year and next year. Activities in the previous year such as the Annual Statistical Report, Year-End Report and Partnership Agreement Audit are carried out from January to April. For example, the Annual Statistical Report and Audit of 2017 projects are carried out in 2018. Similarly, the main activities in the current year include a Biannual Report on the implementation of the current year projects. For the next year, country offices conduct the Country Operation Plan (COP), Detailed Planning, Annual Programme Review, Partners Selection and Retention including preparation of partnership agreements with various implementers of UNHCR supported projects. The sequence of the program cycle begins with an Assessment, followed by planning, Implementation, Monitoring, Reporting, Audit and Evaluation. It is further categorized into three distinct groups; Planning, Implementation and reporting overlapping within a three-year comprehensive plan. In summary, the activities involved in the program management cycle are time-bound and interconnected and therefore, should be linked to the personnel responsible for the oversight. As an organizational issue, the SAL, and the program cycle seem completely disconnected.

To analyses the impact of Staff Assignment Rotation on the Sustainability of projects, we first need to establish the link between the two variables; the independent or predictor variable, Staff Assignment Rotation and the dependent variable, Project Sustainability. As already mentioned, the standard assignment length normally ends on either 30 June or 31 December. The SAL expiry will be 30 June for assignments starting between 1 April and 30 September, and 31 December for assignments starting between 1 October and 31 March. Conversely, the program cycle follows a three-year plan as illustrated above in Figure 1; whereas the SAL duration in non-family duty stations is two years and for Fast Track Positions it is one year. According to the Programme Cycle, critical activities such as Planning are carried out in the following year in the first quadrant (January to March) while reporting is carried out in the previous year (October, November and December) and overlaps to January the following year. These inter-relationships in the various phases of the program cycle are not aligned to the Staff Assignment and Recruitment Policy. The study is intended to draw an analogy and provide an impact analysis of Staff Rotation Assignment and Project Sustainability. In addition, based on reviewed related literature and publications, the following gaps in knowledge relative to the impact of Staff Assignment Rotation on the Sustainability of projects were also contrived:

a) Factors affecting the Success of a Construction Project (Chan, Scott, \& Chan, 2004). The review examined Critical Success Factors (CSF) defined as those factors predicting success on projects (Sanvido et al., 1992). It also looks at the causal relationship between CFS and KPIs. Nevertheless, it falls short of drawing any analogy of those factors; "Quality control, "On-time completion, and Cost "and staff movement or mobility as a component of project critical success factor.

b) Job Rotation as Human Aspects of Management examines the vertical or horizontal movement of men from one position to another for the basic purpose of encouraging and stimulating the growth of the individual. (Morris, 1956). The literature focuses on the individual as a development tool but fails to look at projects or make any comparison on the impact of the visiting or home project.

c) UNHCR's People Strategy 2016-2021, UNHCR Strategic Direction 2017-2021 and mobility in the United Nations Secretariat; (Ickes \& Samuelson, 1987), address various aspects of staff Well-Being and Mental Health.

Despite the publications listed above and although at least 70\% of the organization's annual budget goes into projects for beneficiaries, there are very limited resources, literature or academic writing examining or establishing a relationship between the two variables; Staff Assignment Rotation and Project Sustainability. Therefore, this research will expand the dialogue on Staff Assignment Rotation vis-à-vis Project Sustainability and outline the advantages of harmonizing the project cycle to the policy staff Assignment.

The Objectives of the Study: The purpose of conducting this study is to assess the impact of staff Assignment Rotation on the Sustainability of UNHCR Supported Projects in South Sudan. However, the following specific objectives are also contrived:

- To investigate the relationship between Staff Rotation Assignment vis-à-vis Project Sustainability

- To undertake the Social Impact and Cost-Benefit-Analysis on Projects Life Cycle

- To identify to what extend staff mobility impact project sustainability 
It will also include a recommendation to the change management of the UN Refugee Agency durable and sustainable solutions to the current challenges associated with Staff Assignment Rotation and the impact on the Sustainability of UNHCR Supported Projects in South Sudan and other Humanitarian operations across the globe. This requires a comprehensive review of existing United Nations Statutory documents, circulars and relevant publications.

The study was guided by the following research questions:

- How does Staff Assignment Rotation Impact the Sustainability of UNHCR Supported projects in South Sudan from 2013 to 2016 ?

- How to determine the causal relationship between Staff Assignment Rotation and Project Sustainability

- What are the social impacts of staff rotation assignment on Human and Financial Resources of the UN Refugee Agency vis-a-vis project sustainability?

- What are the acceptable parameters/tools to objectively determine the impact of staff Assignment Rotation on project sustainability?

The Research Question is addressed in the conceptual framework of three distinct components; Independent Variable: Staff Assignment Rotation and Dependent Variable; Project Sustainability. The third element is the Intervening Variable; external factors; i.e. Legislation, Donor Response, Stakeholders' perception and global Refugee Crises. In the context of the UN Refugee Agency, this would require policy changes that would bring fundamental changes in the current Rotation Policy and bring into congruence with the project cycle. One of the key significance of the present study is to provide a comparative analysis of the advantages and disadvantages of Staff Assignment Rotation vis-a-vis Project Sustainability. By extension, the study will also identify any complementary or adverse factors between the two variables. In addition, the result of the costbenefit analysis will enhance our understanding of the measurable impact of the UN Refugee Agency's Mandatory Rotation Policy (UNHCR, 2017a). Another important reason for the study is to outline a conceptual framework that brings synergy between the mandatory staff rotation policy and the PMC (Programme Management Cycle). Aligning the SAL with the Program cycle will reduce staff absence during critical project planning, reporting and implementation phases, and reinforces accountability as responsible staff will remain on the project site throughout the three-year phase. In addition, the study is expected to highlight the need for policy changes that will address the current challenges with the Rotation Policy. Issues related to family separation will not be looked at as personal problems but as institutional and organizational staff welfare challenges that need sustained investment.

It will also benefit the Refugee, our primary people of concern as timelines for project implementation will be reduced as the result of the alignment of the project cycle to Staff Assignment Rotation. The savings from the practice of a two-month extension of the project liquidation period due to the non-completion of projects as per the signed PPA (Project Partners Agreement) would be utilized to address funding shortfall and undertake other key gaps. Savings from internal policy changes will indicate prudent utilization of donor funding which will eventually increase donor confidence with a higher probability of additional resources. Furthermore, the outcome of the research could be a pacesetter for future researchers in the unexplored territory as there is little literature on the integrated approach of Staff Assignment Rotation and Project Sustainability. Finally, the model and framework developed from this research could be used by sister UN Agencies and the humanitarian community at large. This research is limited to the UN Refugee Agency's supported projects in South Sudan from 2013 to 2016. Data will be collected from UNHCR Staff involved directly in project implementation and project monitoring and beneficiaries. However, challenges may include the willingness of staff to provide comprehensive responses especially those critical to the organization, the identification of beneficiaries who can comprehend the question and respond accordingly. Those may be addressed by greater involvement of participants and in compliance with the data collection ethics and assuring them of the safety of their information.

\section{Review of Related Literature}

Conceptual Review: As highlighted in a statement by the UN High Commissioner for Refugee, Filippo Grandi on World Refugee Day, 2018, in the last six decades since the UN General Assembly mandated UNHCR to 
provide international protection to Refugees, there has been an unfortunate decline in peace and co-existence in many parts of the world resulting to an unprecedented 6.8 million people uprooted around the world primarily due to conflicts. For UNHCR to respond to these large-scale humanitarian crises and provide protection and assistance to the ever-increasing number of Refugees and Internally Displaced, requires the services of its staff, both regular and affiliated workforce. Furthermore, as most human displacements are in deep field locations; very often designated non-family due to the hardship classification, International Professional staff assigned to these locations are subject to the "Mandatory Rotation Policy". This Literature review examines the conceptual framework of the policy, the "UNHCR's People's Strategy 2016-2021", International Journals, and looks into how staff assignment rotation impacts project sustainability.

The Finding from the Literature review provided a reasonable argument to ignite discussion on Strategic Management Review of the existing "Mandatory Rotation Policy" and emphasized the need for a similar review of the OMC; (Operations Management Cycle) to align project management with personnel entrusted to provide oversight. Existing literature from academic writing, Policies and Procedures of the United Nations, General Assembly resolutions, and internet sources were used to guide on expectation and likely results of the study. The literature review looked at how Staff Assignment Rotation impacted the Sustainability of UNHCR Supported projects in South Sudan from 2013 to 2016. The study establishes the existence of a causal relationship between the independent variable; staff assignment rotation which is determined by the frequency of the absence of project staff due to the mandatory policy and any abnormality in the dependent variable; project cycle from Initiation, Planning, Implementation, Monitoring, Closure and Evaluation consequently resulting to overrun in terms of budget, completion date and extension of liquidation period which may materially affect the project success.

Figure 1: Conceptual Framework of the Study "Causal Relationship of Independent and Dependent Variables"

Independent Variable

Staff Assignment Rotation:

The frequency of absence from project site measured by the number of the Mandatory Rotation cycle relative to the hardship classification of the duty station

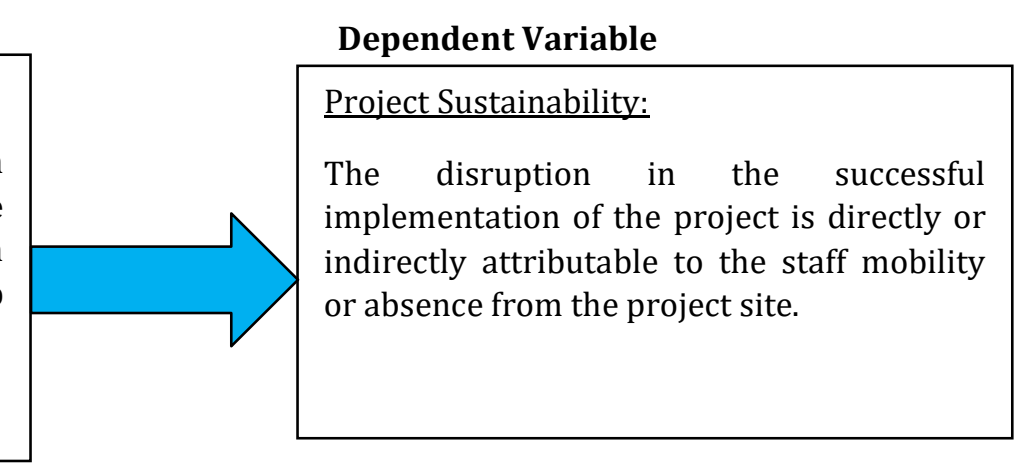

Rotation in the United Nations: Job Rotation is defined as "the planned movement from one position to another for the basic purpose of encouraging and stimulating the growth of the individual." (Morris, 1956: 1). This brings into question the duration and nature relative to the potential impact on project sustainability. For this review, "Staff Assignment Rotation" is contextualized to mean "Professional/functional mobility" defined as "the movement of staff between different functions/occupational groups, whether this implies a geographical move or not", (Morris, 1956: 1). Job Rotation is also looked at from the perspective of "prevention of corruption" (Ickes \& Samuelson, 1987) and further expanded to include Employee training and motivation as key factors of Job Rotation (Eriksson \& Ortega 2006).

Staff Assignment Rotation vis-à-vis Project Sustainability: UNHCR's People's Strategy 2016-2021 (3.3 \& 3.2) addresses two aspects of staff Rotation: Mobility fairly and efficiently and maximizing the potential of different workforce arrangements. It also looks at the modality of responding to protection needs and the involvement of diverse talents in addressing humanitarian crises. Analoui and Samour (2012) on the other hand provided an in-depth understanding of the connectivity between Mobility, Policies and Practices to include governance and management structure. These findings were further corroborated by the model of Ortega who emphasized learning as the primary objective than specialization (Ortega, 2001). Zeff (2003) documents intra-firm correspondence at E.I. du Pont de Nemours \& Company (Dupont). One of the critical looks at job rotation from the perspective of delegation and integration of functions. Having read from the 
various literature outlined above, here is a consensus on the importance of "filing knowledge gap". However, the approach and methodology of analyzing "staff rotation vis-à-vis project sustainability" in the context of "Non-Profit Humanitarian support" are significantly different from the approach of "knowledge exchange" as emphasized by Ortega (2001). Furthermore, and despite these merits, the reviews fall short of linking the Mandatory Staff Rotation Policy (UNHCR/AI/2017/7/Rev.1) to the Program Management Cycle as references in Figure $1 \& 2$ one of the reasons for conducting this research.

Factors Affecting Project Success and Sustainability: The review examined several variables influencing the success of project implementation primarily looking at specific factors relative to KPI (Key Performance Indicators) and CSFs (Critical Success Factors). CSF is defined "as those factors predicting success on projects" (Sanvido et al., 1992). It further evaluated the "causal relationship between the two variables; CSF and KPI" (Analoui and Samour, 2012). The causes of project failure were examined to establish any causal relationship between Staff Assignment Rotation and Project Sustainability. Drawing from the propositions by Budzier, Alexander and Flyvbjerg (2013), we identified the following as key factors that could potentially affect project Success: Stability, Certainty and Controllability under the greater umbrella of Decision Making.

Strategic Decision Making: The critical factor in determining the sustainability of an organization especially in the Humanitarian arena is its ability to formulate strategies that have the required resilience to internal and external changes and the dwindling resources and increasing demand (Analoui and Samour, 2012). Therefore, one of the cut-crossing phenomena is the organization's decision-making, learning and risk management. In the context of this research, the mutual exclusivity of the UN Refugee Agency's Mandatory Rotation Policy (UNHCR/AI/2017/7/Rev.1) as a unique parameter from the project life cycle was viewed as an element of "uncertainty" deemed a substantial risk factor. Others include Stability, Certainty and Controllability. Further reading also revealed that Community Awareness, Participation and Acceptance are key factors in project sustainability. About Staff Assignment Rotation with intermittent duration and frequent disruption due to absence from the project site, sustained engagement through participation in project Initiation, Design and implementation with all stakeholders may not be fully maximized (Oronge et al., 2014).

Key Performance Indicators (KPI) of Project Success: KPI reviews the performance measurement based on the established benchmark (Neely, 1995). Additionally, Analoui and Samour (2012) highlighted six KPIs in the context of a construction project among which are "Quality control, "On-time completion, and Cost". Contextualizing to the framework of the Humanitarian Service Delivery Framework, that is, the UN Refugee Agency in relations to the "Mandatory Staff Rotation Policy" mobility may expose the company to higher cost and extension in the project liquidation period (Morris, 1956) which may adversely affect the current budget structure. Furthermore, relative to my research objective of determining the "Impact of Staff Rotation Assignment on the Sustainability of UNHCR Supported projects in South Sudan (2013-2016)", I will only deliberate on Project Related Factors and Project Management Actions. Walker (1995) contends that "project scope" is a major predictor in project management." This is evident by the limit of this research to CSFs vis-àvis KPI. Comparatively, the scope of my research is limited in duration: 2013-2016, setting: South Sudan; nature: projects supported by UNHCR and therefore the finding from this research cannot be generalized.

Theoretical Reviews: According to the UN Refugee Agency; "Mandatory Rotation Policy" is defined as the movement of International Professional Staff from one duty station as a statutory requirement from one duty station to another in a structured and time-bound manner based on the hardship classification; Fig.1 p.5. UNHCR/AI/2017/7/Rev.1. Outside the confined context of this definition, staff rotation is synonymous with the expatriate assignment. "Expatriates are defined as employees of an organization, sent from one country to another temporarily to complete a task or achieve an organizational goal" (Harrison et al., 2004). International assignments are usually characterized by difficulty regarding personal adjustment, interpersonal relations and task performance (Park, Hwang, \& Harrison, 1996). Similarly, similar studies (Dalton \& Chrobot-Mason, 2007; Magnusson, Baak, Zdravkovic, Staub, \& Amine, 2008) also expanded on the subject emphasizing the difficulty in managing an ethnically diverse workplace environment. Generally, rotation is also associated with attempting to integrate into a new culture and work environment. The degree and success of assimilation or such integration will largely depend on the demography; (Olsen \& Martins, 2009), and community acceptance (Jordar, Kostova, \& Ravlin, 2007). From the audit perspective, the Mandatory Rotation Policy emphasizes accountability and independence. 
As stated by (Harrison et al., 2004) the temporary assignment is designed to accomplish a specific task based on which the duration of the assignment is fixed. On the contrary, the Mandatory Policy of the UN Refugee Agency is a primarily pre-determined timeline based on the hardship classification indicated in Fig.1 page 5 and irrespective of the task. Zeff (2003) documents intra-firm correspondence at E.I. du Pont de Nemours \& Company (Dupont). One of the critical components of project sustainability is the interpersonal relationship with the different actors during the project phases; Initiation, Planning, Implementation and Monitoring, Closure and Evaluation. (Ashforth \& Mael, 1989). In the context of the research, the assignment duration is a key factor in understanding "human action within an organizational framework" (Albert et al., 2000, p. 14), an enabler for great understanding among the various stakeholders. Based on the premise, there is a causal relationship between the degrees of understanding human action to the length of stay at the project site. Relative to the "Mandatory Staff Rotation Policy", the disruption is rather not a positive element of project sustainability.

\section{Figure 2: Maslow's Hierarchy of Needs}

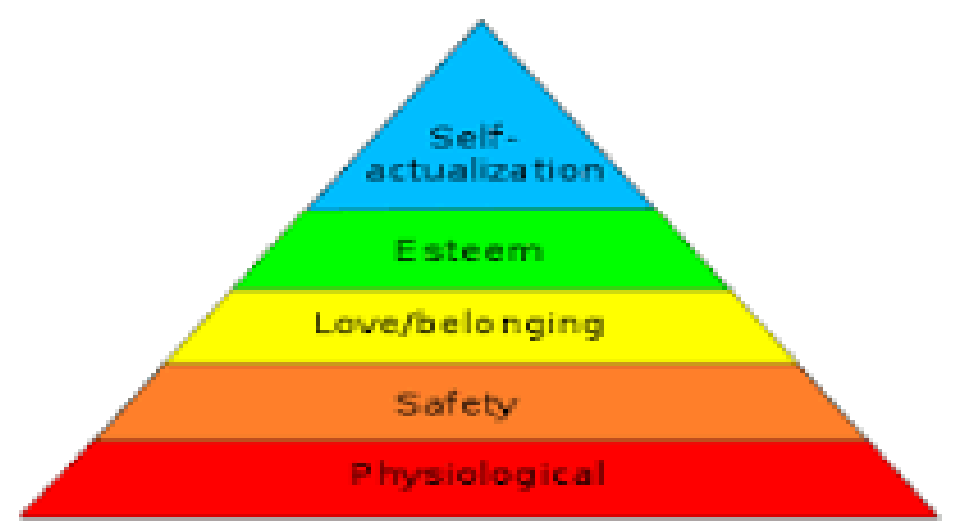

Maslow's hierarchy of needs is represented as a pyramid with the more basic needs at the bottom. Reference to the Convention and Protocol Relating to the Status of Refuges 1951 and 1967 under Resolution 2198 (XXI) adopted by the United Nations General Assembly; grounded in Article 14 of the Universal Declaration of human rights 1948 recognizes the right of persons to seek asylum from persecution in other countries. This is specifically related to Maslow's Hierarchy of needs and no coincidence that the UN Refugee Agency's primary focus is to provide these basic needs "Food, Water and Shelter" referred to by Maslow as "Psychological Need". However, in the specific context of Refugees whose primary reason to flee is the fear of persecution, this may be contrary to Maslow's theory of needs in the context of the Refugees, the most important need is Safety and takes precedence over Psychological need. According to Oleson, 2004, there is a positive correlation between Maslow's hierarchy of needs and the monetary value of these basic services. This is affirmative in the general perspective; however, again it demonstrates the unique attribute of the specific context of Refugees many of whom saw horrific crimes being committed, rape, torture and killing. Their primary need is preserving life and living in safety followed by basic needs; food, water and shelter.

Empirical Reviews: Project Management Action", Hubbard (1990) and "management tool" Jaselskis and Ashley (1991) are key in determining project success. Naturally one would think that ensuring "Project Management Actions" are fully implemented guarantees project success. However, according to Sanvido, et al. (1990), the expectation among all the stakeholders is not the same with regards to what constitutes the success of a project (Olayisade \& Awolusi, 2021). This brings us to the three-dimensional models of project management; "leadership, relationship and beyond leading and managing" Briner et al. (1996). The Literature on "Advancing Project Management in Learning Organization" (Bourne, 2003) emphasizes on "Project Leader" "involving controlling project's deliverables and managing project stakeholder's different expectations successfully". It also requires providing oversight throughout the various project phases (Bourne and Walker, 2003). Relating to the role of the project manager and his responsibilities outlined above to my research "Staff Rotation Assignment ..." and the lack of synchronization with the project life cycle, characterized by the temporary absence from the project site denotes a lack of consistency. This eventually hampers the effectiveness of the project implementation. 
The third dimension of the review is "Corporate Social Responsibility" between and among the various, stakeholders. Morimoto et al. (2004). According to Ortega (2001), "Project Management" is also about managing change. Therefore, to ensure project sustainability, "change" must be managed with consistency and in a well-defined structure. Staff Rotation Assignment could result in temporary loss of efficiency because of the disruption and also due to the time rotating staff needs to adapt and understand the operational context of the new environment (Morris, 1956: 1). Nevertheless, these could be addressed through efficient change management; aligning the project cycle to the length of staff assignment. The review enlightens us on the different aspects of staff rotation assignment about Project Sustainability. It emphasized business continuity; ensuring consistency in the project management throughout the phases from imitation to project closure. Different writers unanimously outlined the significance of training, experience, learning, and critically examined the advantages and disadvantages of the mandatory rotation policy. Bourne and Walker (2003) specifically stressed the need to support "project managers" in developing their skills beyond "leading and managing".

Corporate Responsibility from the perspective of Stakeholder power dynamics and their different expectations on project success beyond meeting deadline, scope, schedule and cost was examined (Bourne and Walker, 2003). Though nothing is definite at this stage, however, there is a stronger indication of an impact both positive; (capacity building and community empowerment" and negative; (temporary absence from project site a critical factor for project failure) of staff assignment rotation on project sustainability. Nevertheless, Chapter III on Methodology and Data Analysis in Chapter IV and potential future research will provide statistical evidence on the frequency to determine the actual impact. Interestingly, despite navigating through these various publications and websites, I could not find any single paper linking Staff Assignment Rotation to Project Sustainability. What I did was conceptualized and draws inferences. Quantitative method and hypothesis testing were predominant among the researchers. The question of whether there is a causal relationship between Staff Assignment Rotation and Project Sustainability both socially and economically has not been sufficiently proven especially by quantifiable verified numerical variables.

In this research, we critically examined the UN Refugee Agency Mandatory Policy, (UNHCR/AI/2017/7/Rev.1), the UNHCR's People Strategy, 2016-2021 with emphasis on the response mechanism to large scale humanitarian crises concomitantly with ensuring the well-being and security of its personnel. To provide a wider perspective with the Humanitarian sphere, we also reviewed "Mobility in the United Nations" (Ickes \& Samuelson, 1987), a discussion paper by the United Nations Staff Union at Vienna, submitted to the XXXI Session of the Staff Management Coordination Committee in Beirut, June 2010. This paper looked at the advantages and disadvantages of Job Rotation, Intra and Inter-Mobility within the context of professional/functional and geographical arena as part of the "Programme for Reform" promulgated by the UN Secretary-General in 1979. Outside the work environment of the UN Refugee Agency and the UN body, we looked at factors affecting project sustainability beyond donor's support (Bourne and Walker, 2003); emphasizing the role of community-based organizations (CBO), Faith-Based Organizations (FBO), and NonGovernmental Organizations (NGOs) and how these interventions impact project sustainability.

One key element that stands out is the fact that these organizations are permanently based at the project site and can address issues promptly. The continuity and longevity of project sustainability vis-à-vis staff rotation would require a further study that could potentially the causal relationship. One of the limitations of the study is the scope; UNHCR Supported Projects in South Sudan from 2013-2016. During the period under review, South Sudan was the newest country in the world with its first independence, July 9, 2011. Secondly, due to the intensity of human displacement, the nature of the humanitarian intervention was primarily Lifesaving. Therefore, due to these specific attributes, the findings from the research cannot be generalized.

\section{Methodology}

The research followed the qualitative methodology predicated on the "philosophical Dimensions" of Constructivism and Interpretivist (Kalof, Dan and Dietz 2008; Saunders, Lewis and Thornhill, 2009) on the assumption that there is no single reality and the researcher's responsibility is to examine different possibilities by contextualizing specific aspect of the research (Easterby-Smith et al., 2004). Secondly, the objective of problem-solving relative to "Staff Assignment Rotation vis-à-vis UNHCR Supported Projects in 
South Sudan from 2013-2016 was used to highlight the issues and impact both social and economic. Thirdly, since the research is scope specific and the outcome cannot be generalized, this is best analyzed using the Qualitative method. Furthermore, the research approach of Inductive reasoning and the method of In-depth interview and focus group discussion were used as the data collection and analysis tools and techniques and deemed appropriate to fully understand the social dynamics of the impact of Staff Assignment Rotation on Project Sustainability (Olayisade \& Awolusi, 2021; Akeke, Akeke \& Awolusi, 2015; Awolusi, 2012).

The research further delved into the possibility of applying the Quantitative method which is based on the assumption of a single reality or there are true answers (Oladejo \& Awolusi, 2017). The research critically looked at some of the challenges of adopting the Qualitative Methodology including the process of making meaningful interpretation of "complex and context-bound" information into conveying the intended message (Blazi \& Awolusi, 2020). The lack of generation due to the scope-specific nature of the research was analyzed (Mukonga \& Awolusi, 2019; Jonker and Pennink, 2010). Similarly, the study also looked at the limitation of using the quantitative method in addressing the research objective of the researcher's continued engagement with the participants. In comparison, and based on the overarching object for researching Solving problems under Interpretivism (Easterby-Smith et al., 2004), and to look at the causal relationship between the Independent and Dependent variable, the qualitative method was adopted throughout the research primarily because it's continuous intuitive engagement with the various project stakeholders as a major objective of the study which could not be achieved using the Quantitative method and by deductive reasoning (Eze \& Awolusi, 2018).

The participants for the research consisted of 50 individuals drawn from four population groups: Refugees as the primary beneficiaries, humanitarian workers and project staff. As outlined by Cooper \& Schindler (2003), these are the segments of the population with specific attributes relevant to the study. The research adopted the following criteria as a pre-requisite for consideration as a participant or respondent to the questionnaire:

- The respondent must belong to one of the four population groups identified above; Direct Beneficiaries of donor funding, humanitarian workers who worked in South Sudan from 2013 to 2016 and UNHCR Project Staff.

- The minimum requirement for project consideration is those implemented in South Sudan during the scope of the research (2013-2016) and with a monetary value of more than 1 million US dollars and practiced the Mandatory Rotation Policy.

Under the epistemology of Interpretivism, Qualitative data collection was chosen as the research methodology and in-depth interview and focus group discussion as the research techniques in the data collection (Awolusi, Pelser, \& Adelekan, 2016; Awosusi \& Awolusi, 2014). The Data Sampling process recommended by Strauss and Corbin (1998) (Easterly-Smith et al., 2004) was carefully reviewed.

However, open sampling requiring the indiscriminate collection of data was deemed not applicable to the research objective because it has a defined scope; duration, location and specific occupational group. Nevertheless, Axial was partially used to draw a causal relationship between the two variables while selective sampling was adopted as the primary sampling strategy because of the nature of the research; unique population attribute. The research used the Selective Data Sampling Strategy and information was collected through pre-arranged interviews by telephone. The participants consisted of 50 respondents across a diverse spectrum of stakeholders; UNHCR, Partners, Host Community and Beneficiaries involving 8 projects, each with an annual budget of more than 1 million USD, supported by UNHCR in South Sudan from 2013 to 2016. Despite the general perception of the truthfulness of the interviewees, reasonable steps were taken to validate the responses as they may have reasons not to be truthful (Bourne and Walker, 2003). Semistructured in-depth interviews were used and involved both direct questioning using open-ended especially on impact analysis and closed-ended questions for more cost implication on the project sustainability. This involved segment of the sample size based on a specific aspect of the objective. There were five different discussion groups not evenly distributed but based on specific interests and expertise. The group discussed practical experience on a sectoral basis, Health, Education, Water and Sanitation.

Staff who has been involved directly in Rotation Assignment had a unique group discussion and later joined other discussion groups together with program experts who reviewed the OMC; Operations Management 
Cycle in the wrap-up session and notes were taken on the challenges and would be subjected to further scrutiny to determine any causal relationship between the variables. The research looked and different ethical issues that may potentially affect the quality of the data. These included the independence of the respondent, data security among others. However, the confidentiality of the respondents was identified as the most crucial element that the data collection environment must ensure. Coding was used to identify respondents and respondents were informed discreetly ensuring organizational policies are also adhered to. Furthermore, standard safeguards were put in place during the data collection process. The study also ensured respect for cultural diversity and sensitivity in the process. The quality of our decision-making is primarily predicated on the validity and reliability of the data and how they are analyzed either as a tradeoff between accuracy and effort (Payne et al., 1988); best or good enough (Simon, 1955). The analysis contained in this research report examined responses from two data collection methods; an In-depth interview and Focus Group Discussion. The results provided a reasonable indication of the existence of an impact at various levels between "Staff Assignment Rotation and Project Sustainability".

Though the setting is South Sudan, nevertheless since most of the staff interviewed have moved on similar rotation to other operations, the trend and impact level largely remained the same though the specific context of South Sudan weighed heavily among other operations due it specific heightening security and reduced rotation of 4 weeks as compared to many ranging between 6 to 8 weeks. Qualitative data analysis (QDA) is generally defined as the process of transforming written data such as interviews into meaningful interpretation. For audit and validation purposes, the research ensured proper documentation of the data and kept a record of the process and data collected. Data were coded, labeled and archived for data security, anonymity, confidentiality and easy identification. The five stages of the project cycle from Initiation, Planning, Implementation, Closure and Evaluation were reviewed from the various interview responses, Focus Group Discussions and secondary data for the three years; 2013-2016. This result was analyzed to determine the existence of any causal relationship between Staff Assignment Rotation and Project Sustainability. Narrative Analysis is particularly relevant to the research objective of "Staff Rotation" as it relates to the experience of staff who have served on rotation. In-depth interview as a method is complimented by this form of informal interaction.

\section{Results and Discussion of Findings}

Re-Statement of Research Questions: The study was conducted to answer the following research questions: RQ 1: How does Staff Assignment Rotation Impact the Sustainability of UNHCR Supported projects in South Sudan from 2013 to 2016 ?

RQ 2: How to determine the causal relationship between Staff Assignment Rotation \& Project Sustainability?

RQ 3: What are the social impacts of staff rotation assignment on Human and Financial Resources of the UN Refugee Agency vis-a-vis project sustainability?

RQ 4: What are the acceptable parameters/tools to objectively determine the impact of staff Assignment Rotation on project sustainability?

To put the responses into perspective in addressing these research questions, the chapter was divided into four sections; the Background of respondents, Comparative Analysis focusing on the Frequency of Rotation and the number of projects extended beyond the Liquidation period, taking into account the single most important factor responsible for project overrun. The third component looked at the primary determinants of project sustainability; and finally, the research examined the Relationship between Staff Mobility relative to the Mandatory Rotation Policy and Project Sustainability defined as "meeting the needs of the present without compromising the ability of future generation to meet their own need" (Odunlami, Awosusi, \& Awolusil, 2017). Within these defined parameters relative to the research objective, 49 respondents in total were carefully selected out of which 37 responded thus indicating a total of 370 individual questions, a 75.5 percent response rate.

Background Information and Results: This section provides the background information with regards to the respondents' Functional Responsibilities. It consists of those who evaluate project management; program and project control staff and further expanded to include Protection Staff who deal directly with Refugees and Persons of Concern; those who are directly impacted by the basic services; Health, Wash, Education, Shelter; 
and Management Staff who provide oversight on Staff Rotation. The other aspect looked at the contractual Status of the respondent; both in the International Professional and the National categories. These mixtures provided a divergence view which further validated the independence and objectivity of the data and made the results more credible.

Functional Responsibility: This is best illustrated in Table 1 below which provides a summary of the functional area of the respondents. The results indicated a combined $35.14 \%$ respondents in project control and program those with expert knowledge on project management; $24.32 \%$ those with oversight roles on staff rotation and the greater percentage of $40.54 \%$ to protection and Field who represent the views of the direct beneficiaries, and other stakeholders; host community, Government and the private sector with corporate social responsibilities.

Table 1: Functions of Respondents

\begin{tabular}{llll}
\hline Functions of the Respondents & $\begin{array}{l}\text { Distribution } \\
\text { Individual } \\
\text { Respondents }\end{array}$ & $\begin{array}{l}\text { Total Questions } \\
\text { Responded }\end{array}$ & Percentage \\
\hline Project Control & 5 & 50 & $13.52 \%$ \\
Programme & 8 & 80 & $21.62 \%$ \\
Protection/Field & 15 & 150 & $40.54 \%$ \\
Management/Administration & 9 & 90 & $24.32 \%$ \\
& 37 & 370 & $100 \%$ \\
\hline
\end{tabular}

Contractual Status of Respondents: Reference to Table 1 on functional responsibilities, table 2 looks further into the contractual status of the respondents. Those in the International Professional category to whom the Mandatory Rotation Policy Applies (UNHCR/AI/2017/7/Rev.1 (2017a) with 62.16\% and those in the National and General Service category to whom it doesn't apply with $37.84 \%$. As the objective was to assess the impact of Staff Rotation Assignment which is only applicable to International staff, the higher percentage of $62.16 \%$ reflected in this category further enhances the richness of the study as it portrayed their professional expertise, experience and could relate directly to the impact personally while being fully aware of the emotional attachment and any potential impact on their objective judgment.

Table 2: Contractual Status of Respondents

\begin{tabular}{lll} 
Contractual Status of Respondents & $\begin{array}{l}\text { Distribution } \\
\text { Frequency }\end{array}$ & Percentage \\
\hline International Professional & 23 & $62.16 \%$ \\
National Officer and General Service Staff & 14 & 37.84 \\
Total & 37 & $100 \%$ \\
\hline
\end{tabular}

\section{Comparative Analysis; Frequency of Rotation and Project timeline.}

Rotation Frequency: Table 3 analyzed the frequency of rotation of International Professional Staff and narrowed it to the 23 staff in this category. The result indicates that only 10 had prior experiences before South Sudan. The study critically reviewed the responses vis-à-vis the number of projects extended during this period in this context paying particular attention to their coping mechanism, impact on the projects to deduce any significant variance probably attributed to human action other than the external environment or the mandatory rotation policy.

Table 3: Number of Rotations

\begin{tabular}{llll}
\hline Number of Rotations & $\begin{array}{l}\text { Distribution } \\
\text { Frequency } 1\end{array}$ & Frequency 1+ & Total \\
\hline International Professional Staff & 13 & 10 & 23 \\
\hline
\end{tabular}

Project Analysis: This component illustrated in table 3 looks at three aspects of UNHCR Supported projects in South Sudan from 2013-2016. These include the total PPA (Partnership Project Agreement) signed 
between UNHCR and various partners; secondly, the number of projects extended beyond the liquidation period and thirdly, the identification of the "Single Most Important Factor" responsible for projects overrun either in terms of budget or timeline.

Table 4: Project Analysis

\begin{tabular}{|c|c|c|c|c|c|c|}
\hline Duration & $\begin{array}{l}\text { No of } \\
\text { Projects }\end{array}$ & $\begin{array}{l}\text { Completed } \\
\text { on Time }\end{array}$ & $\begin{array}{l}\text { Liquidation } \\
\text { Period } \\
\text { Extended }\end{array}$ & $\begin{array}{l}\text { Percentage } \\
\text { of } \\
\text { Completion }\end{array}$ & $\begin{array}{l}\text { Percentage } \\
\text { of Extension }\end{array}$ & $\begin{array}{l}\text { Single Most } \\
\text { Important Factor } \\
\text { Attributed to }\end{array}$ \\
\hline 2013 & 42 & 0 & 3 months & $0 \%$ & $100 \%$ & $\begin{array}{lr}\text { Arm conflict } & \text { and } \\
\text { evacuation } & \text { of } \\
\text { Partners' staff } & \end{array}$ \\
\hline 2014 & 30 & 22 & 02 months & $63 \%$ & $27 \%$ & $\begin{array}{lr}\text { Inadequate } & \text { road } \\
\text { infrastructure } & \\
\text { inhibiting } & \text { the } \\
\text { movement } & \text { of } \\
\text { construction } & \\
\text { materials } & \end{array}$ \\
\hline 2015 & 34 & 33 & 02 months & $97 \%$ & $03 \%$ & $\begin{array}{l}\text { Extension of Ajoung } \\
\text { Thok camp to } \\
\text { accommodate new } \\
\text { arrivals }\end{array}$ \\
\hline 2016 & 39 & 39 & 0 month & $100 \%$ & $0 \%$ & $\begin{array}{ll}\text { Amalgamation of } \\
\text { partners due } \\
\text { reduced funding }\end{array}$ \\
\hline Total & 145 & 94 & 07 months & & & \\
\hline
\end{tabular}

Key Determinants affecting Project Sustainability: The In-depth Questions were contextualized into five main components and analyzed in table 4. The responses identified; Staff Rotation, Insecurity, Government Regulations and Donor Funding as the most dominant factors/causes that are most likely to impact Project Sustainability. In the table below, 148 responses were received from 37 individuals who ranked each attribute based on his/her perception, knowledge, experience or expertise. The result revealed that Insecurity was the highly probable cause or factor that affected project sustainability primarily due to lack of access thus resulting in extension of project liquidation period, evacuation of project staff and delay in the transportation of construction materials and eventual budget overrun. $81 \%$ of the respondents believe Security was the most single factor that impacted project sustainability in South Sudan from 2013 to 2016 with Staff Rotation accounting for $16 \%$.

Table 5: Key Determinants Affecting Project Sustainability Questions Considering that the Sustainability of UNHCR Supported Projects in South Sudan from 2013 to 2016 were negatively impacted, thus resulting in extension of project liquidation period, high cost of implementation and sometimes budget overrun. What will you consider as the Single Most Important Factor?

\begin{tabular}{lllllll} 
Attributes & $\begin{array}{l}\text { Not at all } \\
\text { (1) }\end{array}$ & $\begin{array}{l}\text { Not an } \\
\text { important } \\
\text { factor (2) }\end{array}$ & $\begin{array}{l}\text { Moderately } \\
\text { Important } \\
\text { Factor (3) }\end{array}$ & $\begin{array}{l}\text { Very } \\
\text { Important } \\
\text { (4) }\end{array}$ & $\begin{array}{l}\text { Extremely } \\
\text { Important } \\
\text { (5) }\end{array}$ & Total \\
\hline $\begin{array}{l}\text { Staff } \\
\text { Rotation }\end{array}$ & 5 & 2 & 15 & 10 & 6 & 37 \\
$\begin{array}{l}\text { Insecurity } \\
\text { Government }\end{array}$ & 2 & & 2 & 5 & 30 & 37 \\
$\begin{array}{l}\text { Regulations } \\
\text { Funding }\end{array}$ & 1 & 15 & 10 & 5 & 4 & 37 \\
& 8 & 10 & 10 & 14 & 2 & 37 \\
\hline
\end{tabular}


Relationship and Social Impact of Staff Rotation Assignment on Project Sustainability: The responses were unanimous that one of the causes of the conflicts is the deepening ethnic dimension which remains pervasive throughout South Sudan. On the question of the "Social Impact" in the context of Rotation of International Staff, it was generally viewed as positive as it largely diluted this ethnic dimension and added an element of equilibrium, a catalyst for change, stability and neutrality. Despite this overachieving positive response, nevertheless, few believed Rotation was entirely negative as it deprives promotion of national talents. Further research could look into a much deeper comparison as $70 \%$ of the respondents in this research responded positively cataloging knowledge transfer, capacity building, cultural exchange and international funding as the extremely positive social impact of staff assignment rotation. Relative to project sustainability, "knowledge transfer" was singled out as having the greatest impact.

Discussion of Findings: UNHCR's response to large-scale humanitarian crises to deliver on its protection mandate requires the services of its staff to work in deep field locations; very often designated non-family due to its hardship classification. International Professional Staff assigned to these hardship locations are subject to the "Mandatory Rotation Policy". Similarly, in delivering on the protection mandate, various sectors; i.e. Health, Water and Sanitation, Education, and Shelter are projects implemented on behalf of UNHCR by partners. These projects are coordinated under the Operations Management Cycle while staff assigned to manage these activities is administered under the Mandatory Rotation Policy. The findings of the research established the impact of Staff Assignment Rotation on Project Sustainability especially looking at KPIs (Key Performance Indicators) and CSFs (Critical Success Factors) defined "as those factors predicting success on projects" (Bourne and Walker, 2003). Furthermore, the research outcome also alluded to an earlier proposition by Budzier and Flyvbjerg (2013) which identified "Stability", "Certainty" and Controllability" as key factors that affect project sustainability.

This correlation is further demonstrated in Table 5 where 81 percent of the respondents indicated "Security", an overarching component of "Stability" as the single most important factor that impacts project sustainability followed by Staff Assignment Rotation with 16 percent. Though in the specific context of South Sudan and the scope of the study, Staff Assignment Rotation only accounts for less than one-third, nevertheless, critical factors such as Certainty, Controllability and learning which are fundamental requirements in strategic decision making are made much more difficult if staff mobility is not aligned to the project life cycle (Analoui and Samour (2012). There was a congruence between the research finding and previous literature that indicates that Time, Consistency and Leadership remain critical factors that impact project sustainability. (Bourne and Walker, 2003). Analysis of data also revealed that temporary absence from the project site (Morris, 1956) as a consequence of Staff Assignment Rotation led to disruption in project leadership, extension in project liquidation period as indicated in table 3 with 100\% extension in 2013 and $63 \%$ in 2014. Another key factor that the study also reaffirmed as impacting project sustainability as a result of Staff Assignment Rotation was the absence of sustained engagement through participation in project initiation, design, and implementation Orange et al. (2014). Perhaps astonishingly, and despite Key Performance Indicators and Critical Success Factors.

Such as Stability, Certainty, Controllability, Time, Consistency and Leadership which were largely attributed to Staff Assignment Rotation as having the greatest impact on project Sustainability, the findings revealed "Security" as the single most important factor that impact "Project Sustainability" and the Rotation Policy or the temporary disruption as a result of the Mandatory Policy as a secondary factor. This revelation from the responses presented a shift in the research paradigm and provided a landscape that could be explored further. In our previous readings, Relationship with Project Stakeholders was regarded as one of the critical factors that greatly impact Project Sustainability. While this remains valid, nevertheless, the research finds indicate that the level of significance of our interpersonal relationship with different actors during the project phases; Planning, Initiation, Implementation, Monitoring, Closure and Evaluation, (Ashforth \& Mael, 1989), is largely predicated on the Security Environment rather than the presence of project staff during the various phases. In the specific South Sudan context, and depending on the time and severity of the security situation, the entire project team including those not subject to the Mandatory Policy could be evacuated thus making stakeholder relationships, a sustained engagement which are critical factors that impact project sustainability less relevant. 


\section{Conclusion and Policy Recommendations}

The primary reason for conducting this research was to determine the "Impact of Staff Assignment Rotation on the Sustainability of UNHCR Supported Projects in South Sudan from 2013-2016". The following research questions were the road map that guided the study. "How does Staff Assignment Rotation Impact the Sustainability of UNHCR Supported projects in South Sudan from 2013 to 2016?" "How to objectively determine the Social impact of staff Assignment Rotation vis-a-vis project sustainability?" To adequately address these research questions, and based on the primary objective of solving the problem under interpretivism (Easterby-Smith et al., 2004) and to look at the impact and causal relationship between the Independent and the dependent variable; Staff Rotation Assignment vis-à-vis Project Sustainability, Qualitative method was adopted thorough out the research primarily because of its continuous institutive engagement with the various stakeholders. 103 projects were examined between 2013 to 2016 in terms of extension beyond the liquidation period, 49 individuals were selected as respondents and data were collected through Survey Monkey, In-depth Interview and one-to-one discussion. The objective of this analysis was to infer any relationship between numbers of rotations to project timely completion as exhibited in Table 4 From the responses provided during the data collection, it was evident that indeed experience plays a role in project success, nevertheless, the overarching factor that impacted project sustainability was lack of access due to conflict. The study revealed that Lack of access resulting from insecurity had the most dominant effect on project deliverables with $81 \%$ of the respondents from 148 questions in total. Reference Table 4 On the other hand, Staff Rotation could largely account for a secondary factor, a symptom rather than the main factor affecting project sustainability with only $16 \%$.

\section{Conclusion}

Impact of Staff Assignment Rotation on Project Sustainability: Staff Assignment Rotation vis-à-vis Project Sustainability was sub-divided into specific deliverables. Under Staff Assignment Rotation, the research looked at the social impact and examined any causal relationship with non-deliverable project objectives. As illustrated in Table 4, we looked at staff with multiple operations experience as compared with first-time rotation staff. The result indicated that indeed experience played a vital role in decision making and composure and presented a relatively fairer impact on project outcome. Similarly, under Project Sustainability, we critically examined the single most important factor that the respondents considered as "extremely important". This category comprised four elements from the various responses and factors identified during the research, namely: Staff Rotation, Security, Government Regulation and Funding. The finding revealed a clear indication that project sustainability is impacted largely by the Security environment of the project site. Nevertheless, it is also worth mentioning that insecurity has multiple effects on factors that impact Project Sustainability; ranging from lack of access, increased number of rotations as depicted in Figure 2 on (page 06 duty station classification) and higher insurance for movement of goods and personnel.

Project Liquidation Trend Analysis: Reference to Table 5 on Project Analysis; the following trend emerged visibly. In 2013 during the height of the conflict when most of the Humanitarian workers were evacuated due to the armed conflict between the two opposing forces; the President and Vice President, out of 42 UNHCR supported projects, there were zero completed on time. This further affirms the conclusion of the analysis of the respondents that Security is the most important factor that impacts Project Sustainability. In 2014, out of 30 Projects, 22 representing $63 \%$ were completed on time. This period witnessed improvement in the security situation due to the intervention of the International peacekeepers under the United Nation to open a humanitarian corridor for the delivery of medicine and other suppliers. With more International intervention and a gradual increase in access, the number of projects completed in 2015 was $97 \%$ out of 34 projects and in $2016100 \%$ out of 39 projects.

Project Sustainability: Project Sustainability is defined as "meeting the needs of the present without compromising the ability of future generations to meet their own needs" (Eze \& Awolusi, 2018; Bourne and Walker, 2003). During the data collection, more than $50 \%$ of the respondents did not believe in any sustainability in this context under the current security environment. They mentioned visible destruction of property including hospitals and no clear vision into the future of the young generation many of whom are 
currently child soldiers. Similarly, project sustainability was viewed by more than $30 \%$ of the respondents as investing in human capital, changing mindset and more advocacies in peaceful coexistence.

Recommendations: During the process of collecting data, I talked to respondents from a wider spectrum of the humanitarian world with diversity in portfolio and functional responsibilities. These responses complemented by my personal experience over 15 years provided the platform to request the Change Management to "Pause" "Review" and "Reflect" on the current "Mandatory Staff Rotation Policy" vis-à-vis "Operations Management Cycle" and the impact on the effective and efficient delivery of our protection mandate. The remaining recommendations address specific elements of the four research questions. The research finding indicated a direct relationship between Staff Assignment rotations on Project Sustainability in the specific context of South Sudan from 2013 to 2016. Though only 16 percent of the respondents believed that "Staff Rotation Assignment" is the single most important factor that impact project sustainability, nevertheless, taking into account that more than 80 percent of the current staff of 12,000 are field-based who are likely to be part of the Mandatory Rotation Policy, the likelihood and impact are very high. Therefore, the study recommends a comprehensive review of the current "Mandatory Policy" to incorporate an element of flexibility and alignment with the Operations Management Cycle that will reduce the impact of "Stability", "Certainty" and Controllability" as key factors that affect project sustainability. Budzier and Flyvbjerg (2013). The research critically examined three distinct components; project life cycle from Initiation, Planning, Implementation, Monitoring \& Evaluation, and Closure as one; Operations Management Cycle.

As the second and the Standard Assignment Length as the third component to determine how changes in one element alter the result in another. As indicated in Table 4.3.2, the finding provided sufficient data to draw a causal relationship between Staff Assignment Rotation and Project Sustainability. In 2013, all 42 projects representing 100 percent were extended beyond the Project Liquidation period. Though Security was paramount, the absence of staff was a key determinant either due to access or the exercise on mandatory rotation. Therefore, the study recommends the inclusion of alternative means of service delivery to include empowerment of local institutions and local capacity as part of the Business Continuity Plan and avoid temporary disruption of projects. (Morris, 1956). This aspect of the "research question" looked deeper into how projects are designed in the context of the people, their needs and desire and the consequences of our action on the environment being cognizant of the community and its future sustainability. The research finding revealed a considerable disconnect with cooperate social responsibility and the set project deliverables very often quick impact predicated on quantifiable results. My recommendation is for the UN Refugee Agency to invest in long-term productivity in community empowerment projects. Measurable, quantifiable results based on pre-determined benchmarks are less challenging in determining project success.

These include setting goals and objectives; timely delivery and within budget. However, impact analysis especially determining intangible results or social impacts is much more difficult. Therefore, being aware of these complicated conventional and non-conventional parameters, the research looked at Project Delivery; time and budget as key parameters. Based on these observations, the research recommends the establishment of acceptable parameters to adequately measure social impact. The researcher acknowledged the limitations ranging from the scope, duration, time and the fact that there is still an active arm conflict going on thus making a field visit to some of the projects sites difficult. , and the result points to security with 81 percent followed by Staff Assignment Rotation as the primary factor that impact project sustainability, I recommend that the Change Management Section at the UN Refugee Agency undertakes a comprehensive study to look at types of projects that are sustainable in the action arm conflict environment and the possibility of alignment between project duration and staff assignment length (SAL). Though Staff Assignment Rotation only accounts for $16 \%$ of the most important factor that affects project sustainability, nevertheless it was the second most important factor and therefore requires a review.

Implications and Contributions: This study aimed to provide answers to the four research questions regarding the impact of Staff Assignment Rotation on the sustainability of UNHCR Supported Projects in South Sudan. To determine the most important factor that impacts project sustainability, we examined four components that were mentioned most by the respondents; Staff Assignment Rotation, Security, Government 
Regulation and Funding. The finding indicated Security with 81 percent as the most important factor. This finding implies that Security is an external factor and irrespective of any anticipated policy changes, the impact remains infinitesimal and presents a new shift in the research paradigm and program design. The second implication of the study is the overwhelming operational need to align the Operations Management Cycle with the Standard Assignment Length under the Mandatory Rotation Policy, while this may sound simple.

There are policy challenges as the current Mandatory Policy and established timeline was based on staff welfare rather than any of the phases of the project implementation. The third implication is the fact that Security being the most important factor that influences project sustainability falls beyond the mandate of Humanitarian actors. Further responses also revealed that projects designed under the traditional method are not sustainable and therefore require a dramatic change in approach and design. Those changes need the approval of the donor community and all relevant stakeholders including the host government and partners. This research revealed that despite the importance of this topic, it is largely underreported. The outcome provided a paradigm shift and laid the platform that future researchers could develop further. Furthermore, recommendations made to the change management could fill some of the knowledge gaps that currently exist especially the lack of comprehensive study on the impact of the non-alignment of the Operations Management Cycle to the Standard Assignment Length under the Mandatory Rotation Policy.

Most importantly, the research made a sound argument to review the existing project design in a hostile environment with ongoing active arm conflict and where security is the predominant factor. However, the sample size is limited in scope to South Sudan and duration from 2013-2016. While this may reflect a fairly good proportion of staff involved in the Mandatory Staff Rotation in UNHCR as South Sudan presents one of the major operations worldwide, nevertheless due to the specific context, the outcome cannot be generalized. Furthermore, most of the respondents remain active employees of the organization and while their respect their confidentiality, independence and ethical norms of the process may have exercised extreme caution in their responses. The research also recognizes that due to the affinity of the respondents to the organization and personal experience and preference regarding the Mandatory Policy, there is potential for unconscious biases. Through the adoption of different data collection methodology, Survey Monkey, Telephone discussion, In-depth interview, these limitations were largely curtailed. Impact analysis being descriptive presents valuable opportunities for future research, both to ignite policy review and strategic development. The research finding generated a new and exciting arena to explore and redesign a program centered on Security as the most important factor that affects project sustainability. The findings from the research also emphasized the need to compartmentalize our approach in project design predicated on the most important factor that could potentially affect the project's expected outcome.

\section{References}

Akeke, N. I., Akeke, A. R. \& Awolusi, O. D. (2015). The Effect of job satisfaction on organizational commitment among the non-academic staff of tertiary institutions in Ekiti State, Nigeria, International Journal of Interdisciplinary Research Method, 2(1), 25-39.

Albert, S., Ashforth, B. \& Dutton, J. (2000). Organizational Identity and Identification: Charting New Waters and Building New Bridges. The Academy of Management Review, 25(1), 13-17.

Aljazeera. (2017). Famine was declared in part of South Sudan's Unity state. [Online] Available at: https://www.aljazeera.com/news/2017/02/famine-declared-part-south-sudan-unity-state 170220081516802.html [Accessed 21 Sep. 2018].

Analoui, F. \& Samour, A. (2012). Strategic management: the case of NGOs in Palestine. Management Research Review, 35(6), 473-489.

Ashforth, B. \& Mael, F. (1989). Social Identity Theory and the Organization. The Academy of Management Review, 14(1), 20-39.

Awolusi, O. D. (2021). Economic Growth and Socioeconomic Sustainability in BRICS Countries: A Vector Error Correction Modeling Approach, Journal of Economics and Behavioral Studies, 13(3), 1-23.

Awolusi, O. D. \& Atiku, O. S. (2019). Business Process Re-Engineering and Profitability in the Nigerian Oil and Gas Industry: The Mediating Influence of Operational Performance, Information Management and Business Review, 11(3), 13-26. 
Awolusi, O. D., Pelser, T. G. \& Adelekan, A. S. (2016). Determinants of Foreign Direct Investment: New Granger Causality Evidence from Asian and African Economies, Journal of Economics and Behavioral Studies, 8(1), 104-119.

Awosusi, O. O. \& Awolusi, O. D. (2014). Technology Transfer, Foreign Direct Investment and Economic Growth in Nigeria, Africa Development, 39(2),1-20.

Awolusi, O. D., Akeke, N. I. \& Akinruwa, T. E. (2014). Modeling Business Process Re-Engineering and Organizational Performance in the Nigerian Oil and Gas Industry, International Journal of Management Sciences, 3(5), 336-350.

Awolusi, O. D. \& Fakokunde, T. O. (2014). Enterprise resource planning in Nigerian service firms: a structural equation modeling approach, International Journal of Management and Network Economics, 3(2), 123-143.

Awolusi, O. D. \& Onikoyi, A. I. (2014). Cross-Border Mergers and Acquisitions and international business performance of Nigerian manufacturing firms", International Journal of Business and Management Review, 2(4), 47-70.

Awolusi, O. D., Onikoyi, I. A. \& Akamo, T. O. (2015). Human Resource Management and Business Performance: a study of Nigerian Banks in Ado Ekiti Metropolis, International Journal of Management Science, 2(3), $52-64$.

Awosusi, 0. O., Awolusi, O. D. \& Akinsuru, S. (2015). Unlocking Potentials: Transforming Cultures and Improving Results in Nigerian Tertiary Institutions, International Journal of Investment Management and Financial Innovations, 1(4), 89-93.

Awolusi, O. D. (2012). The effects of mergers and acquisitions on Business Performance in the Nigerian banking industry: an empirical analysis, International Journal of Business Performance Management, 13(3/4), 366-385.

Babbie, E. (2010). The Practice of Social Research. 12th ed. Belmont, CA: Wadsworth Cengage Learning.

Blazi, C. \& Awolusi, O. D. (2020). Employee Engagement in Multinational Diverse Organization in Difficult Terrain: A Study of Non-Family Station Organization, Information Management and Business Review, 12(1), 45-62.

Boote, D. \& Beile, P. (2005). Scholars before researchers: On the Centrality of the Dissertation Literature Review in Research Preparation. Educational Researcher, 34(6), 3-15.

Bourne, L. \& Walker, D. H. T. (2003). Tapping into the power lines - the 3rd dimension of project management beyond leading and managing, 17th World Congress on Project Management, Moscow, Russia.

Briner, W., Hastings, C. \& Geddes, M. (1996). Project Leadership, 2nd ed. Gower, Aldershot.

Brown, S. I. \& Eisenhardt, K. (1998). Competing on the Edge: Strategy as Structured Chaos. Boston, Mass: Harvard Business School Press.

Budzier, A. \& Flyvbjerg, B. (2013). Making Sense of the Impact and Importance of Outliers in Project Management Through the use of Power Laws [online]. Proceedings of IRNOP (International Research Network on Organizing by Projects), 11.

Chan, A. P. C., Scott, D. \& Chan, A. P. L. (2004). Factors Affecting the Success of a Construction Project. Journal of Construction Engineering and Management, 130(1), 153-155.

Cooper, D. R. \& Schindler, P. S. (2003). Business Research Methods. New Jersey, NJ: McGraw-Hill Education.

Coyle-Shapiro, J. \& Kessler, I. (2000). Consequences of the Psychological Contract for the Employment Relationship: A Large Scale Survey. Journal of Management Studies, 37(7), 903-930.

Dalton, M. \& Chrobot-Mason, D. (2007). A Theoretical Exploration of Manager and Employee Social Identity, Cultural Values and Identity Conflict Management. International Journal of Cross-Cultural Management, 7(2), 169-183.

Easterby-Smith, M., Jackson, P. \& Thorpe, R. (2004). Management Research. 4th ed. London: SAGE.

Eriksson, T. \& Ortega, J. (2006). The Adoption of Job Rotation: Testing the Theories. Industrial and Labor Relations Review, 59(4), 653-666.

Ethnographic Action Research. (2018). Equal Access Participatory Monitoring and Evaluation Toolkit. [Online] Available at: http://ear.findingavoice.org/dealing/index.html [Accessed 14 Feb. 2018].

Eze, T. O. \& Awolusi, O. D. (2018). Effect of Critical Factors on Expatriate Assignment Performance in the Nigerian Oil and Gas Sector, Global Journal of Interdisciplinary Social Sciences, 7(2), 6-19

Harrison, D., Shaffer, M. A. \& Bhaskar-Shrinivas, P. (2004). Going Places: Roads More and Less Travelled in Research on Expatriate Experiences. In: J. Martocchio, ed., Research in Personnel and Human Resources Management Volume 23. Bingley: Emerald Group Publishing Limited, 199-247. 
Human Rights Watch. (2018). World Report 2018: Events of 2017. [Online] Available at: https://www.hrw.org [Accessed: 2018].

Ickes, B. \& Samuelson, L. (1987). Job Transfers and Incentives in Complex Organizations: Thwarting the Ratchet Effect. The RAND Journal of Economics, 18(2), 275 -286.

Jha, S., Rao, V. \& Woolcock, M. (2007). Governance in the Gullies: Democratic Responsiveness and Leadership in Delhi's Slums. World Development, 35(2), 230-246.

Joardar, A., Kostova, T. \& Ravlin, E. C. (2007). An experimental study of the acceptance of a foreign newcomer into a workgroup. Journal of International Management, 13(4), 513-537.

Jonker, J. \& Pennink, B. (2010). The Essence of Research Methodology: A Concise Guide for Master and Ph.D. Students, Heidelberg: Springer Science \& Business Media.

Kalof, L., Dan, A. \& Dietz, T. (2008). Essentials of social research. New York: McGraw Hill.

Levy, M. (2011). Knowledge retention: minimizing organizational business loss. Journal of Knowledge Management, 15(4), 582-600.

Magaji, N., Awolusi, O. D. \& Akinsuru, S. (2015). Effect of Marketing Strategy on Customer Loyalty in the Nigerian Oil and Gas Industry: The Mediating Role of Consumer Perceived Value, International Journal of Investment Management and Financial Innovations, 1(4), 94-104.

Morimoto, R., Ash, J. \& Hope, C. (2004). Corporate Social Responsibility Audit: From Theory to Practice (2004). The University of Cambridge, Judge Institute of Management Working Paper. (14/2004). [Online]. Available at: https://ssrn.com/abstract=670144 or http://dx.doi.org/10.2139/ssrn.670144 [Accessed: 2018].

Morris, J. R. (1956). Job Rotation, the Journal of Business, 29(4), 268-273. Available at: http;//www.jstor.org/stable/2350810 [Accessed: 2018]

Mukonga, L. M. \& Awolusi, O. D. (2019). Strategic Leadership in the Post-Conflict States: A Study of the Democratic Republic of Congo (DRC), Journal of Social and Development Sciences (ISSN 2221-1152), 10(4), 36-51.

Neely, A., Gregory, M. \& Platts, K. (1995). Performance Measurement System Design, a Literature Review and Research Agenda. International Journal of Operations \& Production Management, 15(4), 80-116.

Odunlami, S. A., Awosusi, O. O. \& AwolusiI, O. D. (2017). The Influence of Leadership Styles on Employees, Performance: A study of Selected Private Universities in Ogun State, Nigeria, Global Journal of Commerce and Management Perspective, 6(2), 5-13.

Oladejo, M. J. \& Awolusi, O. D. (2017). Effect of Work-Family Role Conflicts on Employees' Commitment and Organisational Performance: A study of AKLAD Interlink concept, Nigeria, Global Journal of Commerce and Management Perspective, 7(2), 81-96.

Olayisade, A. \& Awolusi, O. D. (2021). The Effect of Leadership Styles on Employee's Productivity in the Nigerian Oil and Gas Industry, Information Management and Business Review, 13(1), 47-64.

Oleson, M. (2004). Exploring the relationship between money attitudes and Maslow's hierarchy of needs. International Journal of Consumer Studies, 28(1), 83-92.

Olsen, J. \& Martins, L. (2009). The effects of expatriate demographic characteristics on adjustment: A social identity approach. Human Resource Management, 48(2), 311-328.

Onigbinde, I. O., Awolusi, O. D. \& Awosusi, O. O. (2015). Capital Market Operations and Public Projects' Financing in a Developing Economy: An Empirical Evidence from Nigeria, International Journal of Investment Management and Financial Innovations, 1(3), 69-76.

Orange, D. O., Charles, M. R. \& Paul, A. O. (2014). Community Awareness, Participation and Perception about the Road Maintenance Levy Fund Projects in Kenya. Global Journal of Business Research, 8(2), 97-109.

Park, H., Hwang, S. D. \& Harrison, J. K. (1996). Sources and consequences of communication problem in foreign subsidiaries: The case of United States firms in South Korea. International Business Review, 5(1), 79-98.

Payne, J. W., Bettman, J. R. \& Johnson, E. J. (1988). Adaptive strategy selection in decision making, Journal of Experimental Psychology: Learning, Memory and Cognition, 14(3), 534-552.

Sanvido, V., Grobler, F., Parift, K., Guvents, M. \& Coyle, M. (1992). Critical success factors for construction projects. Journal of Construction Engineering and Management, 118(1), 94-111.

Saunders, M., Lewis, P. \& Thornhill, A. (2009). Research methods for business students. 5th ed. London: Pearson Education Limited.

Simon H. A. (1955). A behavioral model of rational choice, The Quarterly Journal of Economics, 69(1), 99-118. 
South Sudan Humanitarian Project. (2018). Home - South Sudan Humanitarian Project. [Online] Available at: http://southsudanhumanitarianproject.com [Accessed 17 Sep. 2018

Strauss, A. \& Corbin, J. (1998). Basics of qualitative research: Techniques and procedures for developing grounded theory (2nd Ed.). Thousand Oaks, CA, US: Sage Publications, Inc.

Statute of the Office of the United Nations High Commissioner. [1950]. UNGA 106; A/RES/428 (V) (14 December 1950). United Nations General Assembly. Draft Convention relating to the Status of Refugees. $14 \quad$ December. 1950, A/RES/429, [online] Available at: http://www.refworld.org/docid/3b00f08a27.html [accessed 17 Sep. 2018] United Nations General Assembly, Protocol Relating to the Status of Refugees. 16 December 1966. A/RES/2198, [online] Available at: http://www.refworld.org/docid/3b00f1cc50.html [accessed 17 Sep. 2018]

United Nations High Commissioner for Refugees (UNHCR). (2017a). Recruitment and Assignments Administrative Instruction. UNHCR Intranet. UNHCR/AI/2017/7/Rev.1. [Online] Available at: https://intranet.unhcr.org/en/policy-guidance/administrative-instructions.html [Accessed: 2018].

United Nations High Commissioner for Refugees. (2017b). UNHCR Annual Global Trends Report: Global Trends Survey. [Online] Available at: http://www.unhcr.org/globaltrends2017/_[Accessed: 2018].

United Nations Populations Division. (2017). World Population Prospects - Population Division - United Nations. [Online] Available at: https://esa.un.org/unpd/wpp/Download/Standard/Population [Accessed 17 Sep. 2018]. http://www.worldlii.org/int/other/UNGA/1950/106.pdf United Nations General Assembly resolution $429(\mathrm{~V})$ of 14 December 1950, available at http://www.unhcr.org/refworld/docid/3b00f08a27.html. 